This item was submitted to Loughborough's Research Repository by the author.

Items in Figshare are protected by copyright, with all rights reserved, unless otherwise indicated.

\title{
Revitalising energy capital project development and execution strategies: Lessons from the energy sector
}

PLEASE CITE THE PUBLISHED VERSION

http://dx.doi.org/10.1080/09537287.2015.1094583

\section{PUBLISHER}

(C) Taylor and Francis

\section{VERSION}

AM (Accepted Manuscript)

\section{PUBLISHER STATEMENT}

This work is made available according to the conditions of the Creative Commons Attribution-NonCommercialNoDerivatives 4.0 International (CC BY-NC-ND 4.0) licence. Full details of this licence are available at: https://creativecommons.org/licenses/by-nc-nd/4.0/

\section{LICENCE}

CC BY-NC-ND 4.0

\section{REPOSITORY RECORD}

Ochieng, Edward G., Andrew Price, Tarila Zuofa, Charles O. Egbu, and Ximing Ruan. 2019. "Revitalising Energy Capital Project Development and Execution Strategies: Lessons from the Energy Sector”. figshare. https://hdl.handle.net/2134/21333. 
Revitalising energy capital project development and execution strategies: Lessons from the energy sector

Edward Godfrey Ochieng, Andrew David Freeman Price, Tarila Zuofa, Charles Egbu and Ximing Ruan

School of the Built Environment, Liverpool John Moores University, Byrom Street, Liverpool, L3 3AF

Department of Civil and Building Engineering, Loughborough University, Leicestershire, UK, LE11 $3 T U$

Department of Business Information Management and Operations, Westminster Business School, University of Westminster, Marylebone, London, UK, NW1 5LS

School of the Built Environment and Architecture, London South Bank University, SE1 OAA

Bristol Business School, University of the West of England, Bristol, BS16 1QY 


\begin{abstract}
This study sought to examine project delivery challenges currently being faced by energy clients and to determine how they could achieve value creation through better alignment of project delivery processes. There are important lessons to be learned from the energy sector on how to deal with the unique operational and project challenges. Four exploratory focus groups were held with twenty senior project management practitioners, to better understand the greatest needs and project management processes in the energy sector. A formal deductive approach was used to examine and evaluate existing and future energy project delivery processes. From the qualitative data, participants recognised the need to introduce science based project techniques such as system dynamics and project predictive analytics in project management processes. Participants further noted that comprehensive innovative project delivery processes and analytical approaches are required to cope with the increasing scale and complexity of energy capital projects.
\end{abstract}

Keywords: Process modelling, Energy project delivery, Capacity planning, Predictive project analytics, System dynamics.

\title{
1. Introduction
}

The pressure to increase production has released an unprecedented wave of capital spending by the energy sector (Mckenna et al., 2006). It is becoming increasingly difficult to ignore increased challenges and opportunities. Statistical reviews from British Petroleum indicate that global energy consumption reached 12,730.4 million tons oil equivalent (Mtoe) in 2013, almost double the consumption from 1980 (BP 2014). According to International Energy Agency (2014), more than $\$ 1.6$ trillion was invested in 2013 in energy supply, a figure that has more than doubled in real terms since 2000 , and further $\$ 130$ billion to improve energy efficiency. As established from the reviewed literature (IEA 2014; Scarlat et al. 2015), renewables are playing a growing role, with annual investing increasing from $\$ 60$ billion in 2000 to a high point approaching $\$ 300$ billion in 2011 , before falling back since to $\$ 250$ billion. Data from (IEA, 2014), further suggest that current investment to improve efficiency over 2012 levels has been estimated at $\$ 130$ billion. This is equivalent to 13 per cent of fossil fuel investment and compares to $\$ 240$ billion in renewable energy sources. More recently, the European Union (2014) indicated that €200 billion will be required to upgrade existing and new 
interconnectors. As suggested by Suresh et al., (2013), major energy capital investments are currently being planned and are underway across all areas of the energy sector; in upstream oil and gas, refining and petrochemicals, in wind and in conventional power generation.

These investments are driven by growing demand for oil and gas, by emission targets and stringent refined product specifications and by future power capacity needs with an ageing generation fleet. However, a number of energy companies may not have thoroughly assessed their processes for ensuring effective management and delivery of program and project governance. International Energy Agency (2014), showed that the energy sector will invest nearly USD 37 trillion globally in energy projects by 2035. Whilst there are varying views about the extent of project budget overspend due to project mismanagement, a conservative estimate widely accepted in the industry is about 10 per cent to 15 per cent, i.e., USD 3.7 trillion to USD 5.6 trillion (Suresh et al., 2014). This suggests that many forthcoming energy capital projects will face significant economical, operational and technical risks (Fulton and Capalino, 2014). For instance, continuing difficulties at the giant Kashagan field in the northern Caspian Sea - where operational setbacks have put production years behind schedule and $\$ 30$ billion over budget - highlight the risks for investors from technically complex projects (Fulton and Capalino, 2014).

To protect investment portfolios and project portfolios from economical risks, technical risks and risks associated with high cost production, governments, asset owners and contractors must scrutinise project portfolios and company capex budgets more thoroughly than they have in the past. As demonstrated by PwC (2014), the voracious global appetite for energy will continue to grow. Rather being inherently aggressive, the energy sector's transition to greater project efficiency and sustainable business models will be a positive experience for energy clients. Conventional project management techniques will be required to ensure long term value creation. The debate has now moved on from just meeting climate change and emission targets to the cost of reliability of energy supply. There is a focus amongst energy clients and governments on what the cost of delivering energy capital projects to the end-user is and how companies can create value and be more efficient. Whilst the need for successful management of energy capital projects is not a new theme, the many recent instances of 
substantially over-budget and behind schedule energy projects have shown that even most energy companies are not able to get it right every time (Suresh et al. 2014).

Although the industry has successfully completed large scale capital projects in the past, the sheer number of concurrent megaprojects around the world is unprecedented (Deloitte 2013; Flyvbjerg 2014; Kjarstad and Johnsson 2009; Wang et al. 2014)). Stakeholders also continuously faced with making important decisions regarding the allocation of scarce resources among investments portfolios that are characterised by substantial uncertainties. Therefore, more novel approaches to the delivery of energy capital projects are needed to deal with specific physical, technical, environmental and economic challenges (Mckenna et al. 2006). Failure to meet these challenges will significantly impede the industry's ability to respond to both the opportunities and challenges presented by the unprecedented wave of capital investments. The wider global recession in 2007 challenged the core operating models responsible for delivering the business strategy of many global energy providers (Mckenna et al. 2006; Berendas 2007; PwC 2009; Ernst and Young 2011; Salazar-Aramayo et al. 2013).

Hence, this study sought to examine project delivery challenges currently being faced by senior energy practitioners and to determine how they could achieve value creation through better alignment of project delivery processes. An extensive literature reviewed highlighted that 'capital project' and 'large capital investments' are often imprecisely used terms that have diverse range of meanings (Flybjerg, 2014; Ochieng et al., 2013; 2014; Rekveldt et al., 2011), with very few studies done on its role in energy project management. It is apparent that both terms refer to any scheme which requires the use of notable amounts of capital, both financial and labour, to undertake and complete. The above definition captures the concept of energy capital project as explored in this paper. Within the context of this manuscript the authors refer to 'energy capital project' as a key term, this encompasses both renewable energy projects and non-renewable energy projects.

The next section presents a detailed review of literature of project management approaches that reflects future needs, practices and project delivery processes in the energy sector. The review of 
literature also encompasses project management complexity in the energy sector. This is followed by an explanation of the method employed to achieve the research aim. The subsequent section presents the findings and a discussion ensues. Conclusions drawn from the previous sections, the associated practical implications and the way forward are presented in the final section.

\section{Need for advancing project management}

Although project management and delivery practices have improved over the past two decades, there are still concerns that the project management techniques in existing bodies of knowledge do not explicate the key characteristics of complex projects (i.e. inter-relationship of energy portfolios, transport infrastructure, process and heavy engineering at a systems of systems level) (Morris 2010; Winter et al. 2006. Studies have revealed that techniques for tracking, measuring and simulating change in mental models have not yet been well established, and neither has a precise process of mapping knowledge (Vennix 1999, 1996; Richardson et al. 1989; Yeo 1993). Kapsali (2011) showed that the management of complexity and uncertainty should include the identification of flexibility and slack, and the ways on how these could be integrated into planning, execution and evaluation, to allow for enough originality to maximise innovativeness.

Another dimension of the problem that characterises the practice of project management relates to project scale. Over the decades project management practice has been based on an assumed fundamental stance of unresponsiveness to differences in scale. As such, the nature and procedures required to manage small projects are too frequently applied for the delivery of mega-scale projects. Orueta and Fainstein (2009) suggested a convergence in the solution characteristics for implementing mega-scale projects in Europe and the Americas, but not for small and medium scale schemes. The assumption of scale indifference solutions means many mega-scale schemes are inadequately addressed, and often lead to the 'failure syndrome' that Flyvbjerg et al. (2003) identified from his studies of several projects. Recent industry reports, for example (KPMG 2000), confirm the growing adoption of project management standards and practices across large numbers of organisations, including the launch of project management centres of excellence within a number of UK government departments (OPSR 2003). 
Despite the number of developments in practice, several authors highlighted that the current conceptual base of project management continues to attract disparagement for its lack of relevance to practice, and as a result, to improved performances of projects across a number of industrial sectors (Hobday 2000; Kloppenborg and Opfer 2000; Koskela and Howell 2002; Meredith 2002; Morris 1994). A considerable body of literature in project management has emerged over the last fifty years and addressed a wide range of approaches to the management of projects, including theory, processes and principles. Interestingly, when appraising the design processing modeling literature (e.g. Eckert and Clarkson 2010; Hales and Gooch 2004; Lindemann et al. 2009; Pahl et al. 2007; Suh 1990; Ulrich and Eppinger 2003), it was found that no specific literature categorised the complex and entangled themes and research issues of energy capital delivery. It is worth noting that process research distillates on descriptive and prescriptive models that describe the design process. From the reviewed literature, it was further found that design processing modeling plays a major role in management of projects. For instance, Horvath (2004) suggested that design process modeling can feature in artifactual processes, implicated processes and design processes. Evidence, from the reviewed literature strongly suggests that there is still a need to introduce new theories about actual project management practice, which would recognise and clarify the complexity of projects and project delivery in the energy sector.

\section{Theorising project management in the energy sector}

As a result of the global presence, economic importance and environmental sensitivity, energy projects come under enormous pressure from different stakeholders. From the reviewed literature (Eweje at al. 2012; Badiru and Osisanya 2013; Morris 2013; Winter et al. 2006), the dynamic and complex nature of energy projects challenge the traditional project management theories and techniques covered in the PMI and APM bodies of knowledge. While the techniques from both bodies have been found to be effective, they highlight limitations especially when they are applied to manage conventional project risks and complexity at strategic, operational, technical and project level. Over the last two decades, there has been increasing concern within the research community that project management theory has been centered around management of projects, and techniques covered in body of knowledge do not elucidate behaviour of complex capital projects (i.e. energy projects, transport infrastructure projects, process projects, heavy engineering and public sector projects) 
(Morris 2013). For this Riis and Pedersen (2003) also proposed the need for an augmentation of current project management practices.

Recent research reveals that there is a lack of science based project techniques such as systems thinking (the process of understanding how things, regarded as systems, influence one another within a whole) and predictive analytics (encompassing a variety of techniques from statistics, modelling, machine learning and data mining that analyse current and historical facts to make predictions) within current processes and often resulting in poor alignment between many corporate business models and project management processes in the energy sector (Feblowitz and Vesset 2013; Kapsali 2011; Morris 2009; Okrie et al. 2012; Yeo 1993). Project management has been developed to cope with the demands of system engineering methodology (Ohara 2009). Ohara (2009) also argued that a larger technical system could be handled only by a group of engineers acquainted with the systems approach rather than those with narrow-depth technological knowledge.

Kapsali (2011) suggested that simulation methodologies have systematically applied systems thinking constructs to projects. For instance, system dynamics provides a holistic picture of the behavior of a system over time and more specifically the system's underlying structure based on behavioural rules, providing a less ambiguous and more condensed frame of communication (Chapman 1998; Lyneis and Ford 2007; Yeo 1993). Kapsali (2011) further asserted that system dynamics is an excellent tool for applying the systems thinking construct of holism, as in providing a "whole picture" of a specific system and most importantly on abstracting its main attributes to show the particular system's pattern of "organised complexity". This means the non-random patterns under which the system adapts and self-organises despite the randomness and serendipity which are inherent within all systems (Cabrera et al., 2008; Weaver, 1984). System dynamic is a very effective tool for rationalising project complexity through formalising behavioural rules (Senge 1990; Forrester 1961). Rodgrigues and Bowers (1996) advocate that system dynamics provides clarity and reveals what should be considered in projects. Recent research suggests that system dynamic hangs between functionalism and interpretivism since it builds an objective representation of reality and models people's subjective interpretations in group modelling sessions (Kapsali 2011; Lyneis and Ford 2007). 
In turbulent economic times, energy organisations need to sharpen their focus on reining in cost, reducing risk and extracting value from projects (Aleklett et al. 2010; Asche et al. 2012; Erdos 2012; Mckenna et al. 2006; Nakhle 2007). There is also a pressing need to establish how energy companies can better leverage their resources to handle increasingly complex projects, streamline and continue to invest in efficient innovative project management processes, and improve supply chain capability and capacity (Mckenna et al. 2006). As well as meeting the challenges of supply security and climate change, the sector has to respond to stakeholder's demands for better quality energy projects at a lower unit cost with reduced deviation of out-turn costs (Gaisford 1986; IEA 2011; Mckenna et al. 2006). While there is some increase in project management research, the research contribution still is detached from problems that practitioners face in industry (Graham 1988; Morris 2010; Winter et al. 2006). Evidence, from the above literature strongly suggests that there is a need to introduce new theories about actual project management practice, which would recognise and clarify the complexity of projects and project delivery in the energy sector.

\section{Underlying complexity of project delivery in the energy sector}

Success in managing energy projects will depend on: managing the project in a turbulent environment, work with a diverse multidisciplinary team, managing functional plans consecutively and interdependently, maintaining a high level of project communication, and monitoring concurrently the utilisation of resources (Lang 1990; Willoughby 2005). For energy contractors this means managing a portfolio of complex projects. The issue of dealing with complexity is the prime focus in today's energy organisations (McComb et al., 2008; Rekveldt 2011).

Project complexity in energy projects can be found in two dimensions: outside the project and inside the project (Badiru and Osisanya, 2013; Mckenna et al., 2006). Li and Guo (2011), present quite a different perspective on project complexity by suggesting that complexity in mega projects can be generated from three different levels: technical, social and managerial. Social complexities of energy projects are determined by unintended impact of mega projects on the environment and social systems within their location of implementation. Managerial complexities originate from business and governance facets of projects including financial arrangement, scheduling, resource classification and decision management. Technical complexities transpire from the design and technologies utilised in 
the construction process (Li and Guo 2011). More recently, Morris (2010) highlighted that most project managers' grapple with technical substantive issues, within the context of commercial and schedule, budget, requirement, specification, and health and safety constraints.

It is crucial that throughout the project life cycle clients and senior managers develop plans and standardise the project with the purpose of managing project complexity (Mckenna et al. 2006; Van der Weijde 2008). As capital project delivery require an outstanding level of management, the use of conventional systems developed for ordinary projects have been found to be unsuitable for complex ones (Li and Guo 2011; Smith and Winter 2010; Piperca and Floricel 2012). The continuous need in engineering projects for speed, cost and quality control, safety in the working environment and avoidance of disputes, together with technological advances, environmental issues and fragmentation of the energy sector, have resulted in a spiraling and hasty increase in the complexity of projects (Mckenna et al. 2006). The complexity has now reached a level where senior managers must consider the influence of conventional methods on the success of capital energy projects.

There is a need to introduce new theories about actual project management practice, which would recognise and clarify the complexity of energy capital projects (Morris 2010). It is worth noting that there are a number of theoretical project management models that might be suitable for the delivery of energy capital projects. In addition, the management of energy capital projects is now a vibrant area of academic interest, attracting a number of new researchers. While there is some increase in research activity, the research contribution remains detached from the problems that practitioners face in industry (Morris 2010). The research community ought to examine the following question: what are the consequences to energy capital project models of complexity? As mentioned earlier on, new novel approaches to delivery and management of energy capital projects are needed to deal with specific environmental, operational, technical, economic and physical challenges (Mckenna et al. 2006). Failure to address these challenges will significantly encumber the industry's ability to deliver complex ventures in an efficient and effective way (Flybjerg, 2014; Rekveldt et al., 2011). It is worth noting that, major energy capital schemes carry a high risk and require a good understanding of the five challenges and capable management. Morris (2010) advocated that project management should be devised so that its significance is clear. 
One of the most significant current discussions in project management is that it has the potential of integrating different fields to focus on a marvel of study, i.e. energy capital projects (Kwak and Anbari 2008; Mckenna et al. 2006; Morris 2010, Winter et al. 2006). It is becoming increasingly difficult to ignore the development of project management (both the practical and theoretical parts of it). While there is some increase in project management research, the field lacks comprehensive studies of processes and concurrent research that would be valuable for understanding elementary issues of projects and project organisations (Midler 1995; Morris 2009; Li and Guo 2011). It would be beneficial to carry out research studies that would build theories for understanding fundamental issues of energy projects. The next section details the research method and a symposium of findings drawn from roundtable discussions with senior practitioners.

\section{Method}

The reviewed literature identified a gap within the previous literature which had not previously been investigated. As established from the reviewed literature (Aleklett et al., 2010; Asche et al., 2012; Erdos, 2012; Mckenna et al., 2006; Nakhle, 2007; Suresh et al., 2014), there has been little attention paid to establish how energy companies can better leverage their resources to handle increasingly complex energy projects. In order to carry out the investigations a research strategy had to be designed which allowed the overarching aim of the study to be achieved. The just reviewed literature took into account the current need to understand how major energy capital projects could impact economies in terms of growth, project efficiency and value creation. The literature search revealed that there were already economic and environmental factors (Eweje at al., 2012; Badiru and Osisanya 2013; Mckenna et al., 2006; Morris, 2013), which influenced the delivery and implementation of energy capital projects. These factors were assumed as integral to everything, which took place in front end loading but rather than attempting to make the connections between the two explicit, the study focused on the experiences of senior executives involved in capital energy project management. This opened up the possibility of developing a clear understanding of capital delivery, in particular the understanding of project delivery processes and challenges.

The overall design of the proposed research was to adopt qualitative approaches. In any qualitative research, data analysis becomes an ongoing process, so the researcher has to make thoughtful and, 
informed decisions throughout the data collection procedure (Bryman, 2012). A formal deductive approach was adopted to examine existing and future energy project management processes. For this study formal deductive procedures included: using dataset as a source of theory building and theory testing by theme matching and generating. This was achieved by exploring and challenging the existing project management theory. A preliminary pilot study was carried out with senior managers in the energy sector. The purpose of the pilot study was to assess clarity of questions and suitability of the respondents for the workshop. The criteria used to identify participants were their abilities to manage large capital energy projects, and have reliable innovative project management capabilities. Four exploratory focus groups were later held to better understand the greatest needs and project management processes in the energy sector.

A qualitative method of data collection was adopted by means of open ended interviews paired with recent projects delivered by each participant. The projects managed by participants were utilised to build background knowledge on energy project delivery processes. This evoked further questions for the interviews, which both strengthened and opposed the opinions of prior research and provided a broader understanding of challenges faced in the energy sector. The interviews were set in structured format, with predetermined questions with the same wording and order, so that the same circumstances would apply for each participant (see appended interview grid). The interview questions were cautiously selected in an attempt to prevent any preconceived bias. It was assumed by Nachmias and Nachmian (1996) that the interviewees would have a sufficiently common vocabulary, so the construed questions would have the same meaning for each of them and that it would be possible to phrase the questions in a format that is meaningful to each participant.

Through using interviews there was the opportunity to explore participant's opinions to protract a more in-depth response, compared to questionnaires which allow for a limited response. The questions allowed additional information to be gathered and further reasoning behind responses to be explored, this allowed for a better understanding behind the participants thinking. As shown in Table 1, the twenty participants comprised of project directors and project managers from UK, Germany, Norway, France and the Netherlands. In addition, the authors selected organisations that had gone through 
extensive advancement in their project management practices. For the purposes of confidentiality, the participants' names and the names of their organisations have been changed.

Table 1: Profile of participants

\begin{tabular}{|c|c|c|c|c|c|}
\hline Participants & $\begin{array}{c}\text { Years of } \\
\text { experience }\end{array}$ & Job title & Organisation & $\begin{array}{c}\text { Projects } \\
\text { managed }\end{array}$ & Country \\
\hline A & 25 & Project director & A & Oil and gas & UK \\
\hline B & 30 & Project director & B & Oil and gas & UK \\
\hline C & 26 & Operation director & B & Oil and gas & UK \\
\hline D & 22 & Project manager & C & Oil and gas & UK \\
\hline E & 35 & Project director & D & Oil and gas & UK \\
\hline F & 32 & Projector director & E & Oil and gas & Norway \\
\hline G & 27 & Project manager & F & Oil and gas & Norway \\
\hline H & 20 & Project manager & G & Oil and gas & Norway \\
\hline I & 33 & Project director & H & Oil and gas & Norway \\
\hline J & 25 & Project manager & I & Oil and gas & Norway \\
\hline K & 23 & Project manager & J & Oil and gas & Germany \\
\hline L & 34 & Project manager & K & Oil and gas & Germany \\
\hline M & 22 & Project manager & L & Oil and gas & Germany \\
\hline N & 20 & Project manager & M & Oil and gas & Germany \\
\hline O & 28 & Project director & N & Oil and gas & Germany \\
\hline P & 24 & Project manager & O & Oil and gas & Netherlands \\
\hline Q & 30 & Project director & P & Oil and gas & Netherlands \\
\hline R & 33 & Project director & Q & Oil and gas & Netherlands \\
\hline S & 29 & Project manager & Q & Oil and gas & Netherlands \\
\hline T & 30 & Project director & R & Oil and gas & Netherlands \\
\hline
\end{tabular}

A series of exploratory discussions (4 sessions) were organised with experienced senior managers from the energy sector to discuss the needs and potentials for improving performance and delivery as well as the implications of current project management process as drivers of future strategic long term thinking. All exploratory discussions were carried out in the UK. Even though the data analysis was placed after the discussions, it was implemented as an ongoing process of the exploratory sessions. Four skilled academic facilitators constantly monitored group dynamics that could have affected responses during the exploratory discussions, which lasted for about six hours. Although many factors have impact on successful focus group creation, several are of particular importance. A sense of purpose was made clear to the participants. Follow-up discussions were later held with senior executives from clients, consultants and supply chain partners to understand strategies for the effective delivery of capital projects in the oil and gas sector. These discussions were followed by a combined session with the four groups to consider the issues raised in the first stage. The discussions 
were recorded and transcribed. The findings were analysed using qualitative data analysis software, NVivo. As for the data analysis, the interpretivist research paradigm was used as the epistemological framework of the study.

According to Bryman (2012), interpretivism involves researchers to interpret elements of the study, thus interpretivism integrates human interest into a study. Accordingly, "interpretive researchers assume that access to reality (given or socially constructed) is only through social constructions such as language, consciousness, shared meanings, and instruments" (Myers, 2008, p.38). Development of interpretivism philosophy is based on the critique of positivism in social sciences. In this study, interpretivism was associated with the philosophical position of idealism, and was used to examine diverse project delivery approaches. The adoption of interpretivisim, allowed the researchers to examine differences in organisations in a great level of depth. The primary data generated via interpretetivism studies might be associated with a high level of validity because data in such studies tends to be trustworthy and honest (Bryman 2012).

This holistic approach of data analysis and a strategy that could be termed as "reflective interpretivism" fitted well with the use of NVivo. One of the primary functions of the software that emerged was the ability to add memos to sections of the data, as thoughts and connections were made during all the phases of the data analysis. It enabled the researchers to sort through the data and at the same time allowed exploration of project delivery processes and challenges in the energy sector. Qualitative researchers (Bryman, 2012; Denzin and Lincoln, 1998; Huberman and Miles, 2002) stress the continuous interconnection of fieldwork and interpretation. Bryman (2012) addressed it as a spherical sequence, whereby the researcher's original theoretical position is continuously altered or refocused by the fieldwork in a dynamic dialectical method. The codification system was drawn from the initial interview questions, which was based on appraisal of key issues arising from initial discussions with senior executives from the energy sector.

In order to familiarise with the data at an early stage, it was important for the researchers to facilitate the data collection process as the first step of analysing data. Each interview transcript was individually broken down into various initial codes, $1^{\text {st }}, 2^{\text {nd }}$ and $3^{\text {rd }}$ level coding. These codes were then 
analysed for commonality and examined for themes. These themes were then revisited and allocated names, by the end of this stage Braun and Clarke (2006), conclude that the researcher should be able to define what the themes are and what they are not. This method of analysing the qualitative data was implemented once the transcripts were completed. The generation of themes was an ongoing and development process, garnered in part by the application of a large number of codes. Two primary codes (or clusters) provided meaningful categories:

- Identifying the greatest needs and/or potential for improving project performance and delivery; and

- Determining if current project management processes act as a focus for strategic long-term thinking?

There was a logical progression in the order of the parent codes. This was an attempt to ensure that the main strategies for energy capital delivery and challenges were identified. Careful consideration was given to how best to cover possible differences in energy capital delivery. A solution was to ensure diversity in the sample, in terms of capital projects delivered by project directors and project managers (see Table 1). Such diversity ensured that potential differences in project management processes and challenges could be identified. As well as considering developments in project complexity and project delivery processes, in terms of capital management, analytics, system dynamics and value creation, and the influences on such developments, a research study of an exploratory nature based on actual project management practice led to tangible suggestions for modification of project delivery processes in the energy sector.

The final group discussion was attended by senior executives from the five countries, European Construction Institute senior members and senior academics from two well established institutions from the UK. The aim of the final group discussion was to validate the key findings of the study. Validity and reliability were achieved by first assessing the plausibility of the strategies proposed. The verification took place after the interpretation of data, this involved presenting the findings to the main participants. The validation took place after the verification process. The final combined session focused on identifying the important challenges to the effective delivery of energy sector projects as 
well as discussing remedial stakeholder actions that sustain the mutual alignment of the project management process.

Rigour was achieved by engaging experienced executives from the energy sector and focusing on verification and validation, this included responsiveness of the researchers during group discussions, methodological coherence, appropriate sampling frame and data analysis. The philosophical consideration of this research can be viewed from two broad perspectives. The first perspective was linked to the essential requirement of investigating the actual project delivery strategies in the energy sector. The second perspective was linked to proposing solutions to challenges identified in the energy sector. The results of the four exploratory focus groups suggested that comprehensive project delivery strategies are needed to cope with the increasing scale and complexity of capital projects in the energy sector. The remainder of this manuscript summarises the findings. It sets out a series of actions to be undertaken to ensure effective delivery of capital projects in the energy sector.

\section{Findings}

The findings are presented below under two themes drawn from the analysis. There was a mutual exchange of ideas with senior energy practitioners throughout the process. Where appropriate, descriptive quotes drawn from the four exploratory discussions have been used to express the views of the senior executives.

6.1 Theme 1: Greatest needs and/or potential for improving project performance and delivery Increased project complexity in demanding project environments, aggressive performance expectations and technological innovations mean that energy organisations must make quantum shifts to be able to deliver energy capital projects. The important shifts include the following:

- Personnel training;

- Integration of intelligent clients;

- Understanding market and risk chains;

- Comprehending legal framework in global environment;

- Understanding constraints and complexity. 
According to participants (A, D, E, F - see Table 1), clients and contractors need to challenge traditional capital development and execution strategies, so that companies can better leverage their internal scale and scarce internal resources to handle increasingly complex capital projects. In this era of complex capital projects, rewards are larger-and risks are greater. Participants affirmed that energy organisations cannot afford to miscalculate the complex risks. While risk management is not a new concept for energy organisations, complex commercial arrangements, increased technical challenges, evolving local conditions (both economic and regulatory), and a portfolio that is shifting geographically toward frontier regions are all increasing the risk of schedule and cost overruns (Graham 1988; Mckenna et al. 2006; Van der Weijde 2008). Risk management is an issue in terms of technological advances, which continue to be key competitive drivers. For instance, producing wells now go to depths beyond 7,500 feet, while exploration has plunged to 10,000 feet (Mckenna et al. 2006). The adoption of new technologies has added to further project complexity to project delivery. Participants further highlighted that both (local and international) economic and regulatory conditions represent significant sources of risk. Participants also pointed out that a very tight labour market has led to significant project delays and cost overruns in Europe. Specifically, Participant A, noted that:

Globally, energy companies have been struggling to secure skilled personnel and supplybase capacity to meet an aggressive wave of capital investment.

None of the above risks are new, however, the participants suggested that the risks are now more complex to manage because they entail new technologies, more stakeholders and more complicated host countries. The reviewed literature (Mckenna et al. 2006; OGER 2011; 2013), also indicate that contractors share these concerns but with a heightened sense of urgency. They believe that, energy organisations do not fully examine, recognise and manage the risks, and consequently are not mitigating them effectively. From the discussions, it was highlighted that not all energy clients have yet fully developed their in-house capabilities and developed the inter-related capability as intelligent clients of the future. A number of the clients have already embarked on change programmes that will enhance their capability for the future. According to Pinsent Mason (2011), intelligent clients should bring together in-house and inter-related capabilities, including expertise in procurement and contracting strategy, design and technological know-how, capital and programme management as 
well as facility management and asset management capabilities, knowledge of project finance, understanding of alternative models of programme governance, leadership and stakeholder management skills.

Project delivery in the energy sector is becoming flawless, evolving towards a single marketplace that surpasses national borders (Kjarstad and Johnsson 2009; Mohr and Evans 2010). Participants (C, D, $F, G, H$ ), further indicated that with continuous regulatory, legislative and judicial adjustments, energy organisations operating across borders will be challenged to follow and appreciate ever-changing global developments in the market. Strategic adjustments, globalisation, economic realisms and operational change will require energy companies to follow and identify with strategic internal proposals. The integration of the above streams will require energy companies to be flexible and wellversed in global economic developments (Ochieng et al. 2013; Ochieng et al. 2014). They will need to understand the tax impact on global business operations. It could be argued that simplifying organisational structures will enable energy companies to enhance operational efficiency.

6.2 Theme 2: Current project management processes in capital delivery

The current project management processes identified in capital delivery were:

- Front end loading;

- Manage uncertainty during contracting execution;

- Data management and use of analytics and system dynamic;

- Capacity development mechanisms;

- Dynamic global environment-project management processes need to continue evolving;

- Competencies in workforce (contractors, employment law).

The twenty participants suggested that front end loading involves developing sufficient strategic data with which project directors and project managers can use to address risk and make decisions to commit resources in order to maximise the potential for success and capital expenditure. According to the participants, the success of front end loading will depend on risk management and development of well integrated technical project teams. This finding shows that a capital project with a 
systematically performed front end loading, in which the risks have been mapped will face unexpected problems during delivery. In their study, Flybjerg et al. (2003) affirmed that risks in projects cannot be eliminated. Flybjerg et al. (2003) advocate a more explicit acknowledgement of risk with a more accountable approach before the investment decision is made.

Morris (2003), Dingle (1985) and Van Der Weijde 2008 found that effort invested in the front end significantly influences the eventual project performance in general. Interestingly, the twenty participants appreciated that a well-executed front-end loading development phase is an important indicator in overall project performance. The findings show that energy organisations need to invest in front end loading. A number of factors, including front-end planning, approvals process and regulations can cause shortcomings in delivery. When asked how they went about implementing front end loading, most participants stated that front end loading approach requires extensive identification, evaluation and optimisation of probable development scenarios. Participants also indicated that a front end loading framework should consist of pre-concept, concept, pre-feasibility, feasibility, implementation, operation and post implementation review.

As observed in this theme, participants suggested that the benefits of detailed pre-project planning are fewer changes and surprises at later project phases, which directly translates into lower costs and less schedule variance. The findings are consistent with those of Steffen et al. (2008) and Willink (2005). Research carried out by Independent Project Analysis and the US Construction Industry Institute also recognise that effective front end loading can decrease project costs on average by up to 20 per cent compared with less efficiently planned projects irrespective of project size (Steffen et al. 2008; Willink 2005). Energy organisations need to implement an all-inclusive plan that will accurately account for uncertainties through all phases of development. Participants highlighted that the characteristics of today's large capital energy projects have added new challenge to delivery. Participant $(\mathrm{C}, \mathrm{H}$, and $\mathrm{J}$ ) further highlighted that, globally, oil and gas production is moving increasingly to remote sites where infrastructure and labour resources are limited.

As energy capital projects are becoming complex, participants acknowledged that comprehensive innovative project management and analytical approaches are required to cope with the increasing 
scale and complexity of capital oil and gas projects. For instance, science based project techniques such as systems thinking, data and analytics are required to compare estimates on past projects, review variances and analysing causes (Kapsali 2011; Okrie et al. 2012; Yeo 1993). Understanding past project issues, backed by solid information rather than premonition, enables better up-front planning, forecasting and estimates (Dingle 1985; Frizelle 1993; Van Der Weijde 2008). It was also discussed by the participants, that capacity mechanisms can be used to minimise uncertainty. Capacity project decisions can be complicated by the nature of the associated project supply chain. A capital project may require special consideration at more than one phase of the project. In such cases, the capacity investment decision must consider multiple phases and chain capacity decisions can be mapped into a single phase (i.e. front end loading).

Capacity expansion problems have been examined in the operations literature since the late 1950's, with the vast majority of literature focusing on the timing and quantity of investments given deterministic future demand for a single product (Manne 1967). Capacity decisions in energy projects are made when oil discovery brings cost uncertainty, production planning, which maximises profit subject to capacity constraints concerns. Participants recognised the importance of science based project techniques such as system dynamic and project predictive analytics. According to Participant (C), their strategy for the upcoming years is to continue to grow and strengthen recent successes with more robust systems and project management processes through 'World Class Project Delivery' leading to improved outcomes (measured as Cost/Time; Quality/Value; Expectations met; Reputation). In order to improve the performance in practice, participant (C) suggested the following as five key areas that could be grouped under 'World Class Project Management Delivery': project definition, organisational/operating model, adding value, controls and project governance and associated standards.

More than half of the participants said they were dissatisfied with their companies' over-all project performance, citing the costly budget and schedule overruns that plague 30-40 per cent of their project. This finding seems to be consistent with the Booz Allen Report (Mckenna et al. 2006). Major energy companies are less satisfied with overall project performance now than, perhaps, at any time in the industry's history (Mckenna et al. 2006). In particular, they are dissatisfied with project 
management performance, risk management, and human resources management. Engineering Procurement and Construction (EPC) firms share their clients concerns. They are less pleased with performance and are further disturbed by lack of collaborative project planning on part of owners. Operational managers, specialist contractors and suppliers are often excluded from early decisions which have the greatest direct influence in capital delivery and performance (Berendas 2007; Gaisford 1986; Graham 1988). The optimal early involvement of operational managers and specialist contractors in front-end development is therefore critical to improving efficiency, risk management and productivity.

Participants emphasised that, there is no global framework to match the global nature of oil business operations. As has been witnessed with the response to climate change, international agreements can be very hard to negotiate and implement (Aleklett 2010; Erdos 2012; Mckenna et al. 2006). Some specialist contractors are operating at a level of integration unmatched by the legal systems of the various countries that they operate in. This means that a contractor based in one country must comply with the rules of its 'home' country but it must also and concurrently conform to the law in any other country in which it operates (Ochieng et al. 2013). According to the participants, one way in which home energy companies can address this issue is to set up a joint venture with one or more local contractors from the target country or zone. The appropriate local contractor(s) will be networked within their sphere of activity and have the necessary legal awareness to operate effectively within the local or regional market. Joint venturing can be a creative process, and one in which both contractors harmonise their individual strengths so as to create a more effective organisation (Ochieng and Price 2009; Ochieng et al. 2013). It is worth highlighting that the aging workforce has further added to the resource constraints and challenges. Participants suggested that the global energy sector is suffering from shortages of skilled project directors and project managers. This is similar to Accenture (2012) findings, which showed energy companies are struggling to find people with "STEM" skill-advanced knowledge of science, technology, engineering and mathematics.

\section{Discussion}

The results in this study show that clients and contractors in the energy sector need to challenge traditional project delivery strategies. It was widely recognised that in this era of capital project delivery the rewards are larger and risks are greater. Participants affirmed that energy organisations 
cannot afford to miscalculate the complex risks. For instance, both (local and international) economic and regulatory conditions represent significant source of risk in the sector. As mentioned in the findings, risks are now more complex to manage because they entail new technologies, different team cultures, more stakeholders and more complicated host countries.

The overwhelming view of all participants is that, the global oil and gas production is moving increasingly to remote sites where infrastructure and labour resources are limited. As oil and gas projects are becoming complex, innovative project management and analytical approaches are required to cope with the increasing knowledge ecosystem. Science based project techniques such as systems thinking, data and predictive project analytics are required to compare estimates on past projects, review variances and analyse causes. System dynamics project models have been applied to investigate risk management as an aspect of project management distinct from project control (Lyneis and Ford 2007). The structures that system dynamicists have used to model projects can be categorised in four clusters based on the central concept that they integrate into project models. The categorisation provides a meta-structure of project model structures. The four model structure clusters are: project features, a rework cycle, project control and ripple and knock-on effects (Lyneis and Ford 2007).

According to Okrie et al. (2012), through predictive analytics, organisations can identify and avoid failure by better understanding project complexity against the maturity of existing controls and governance models. As a result, financial, productivity and reputation-based loses can be minimised, whilst internal attributes that contribute to project delivery and success are reinforced. Predictive Project Analytics (PPA) is a project risk management model that provides prudence on potential complex risks and where immediate fixes for in-flight projects and programs (at any phase of the project) can be implemented to mitigate risk (Okrie et al. 2012). Understanding past project issues, backed by system dynamics models, PPA and solid information rather than premonition, will enable energy organisations to better up-front planning, forecasting and estimates.

A key finding from the considerable input made by all participants is that intelligent clients should bring together in-house inter-related capabilities, including expertise in procurement and contracting 
strategy and technological know-how, capital and programme management as well as facility management and asset management capabilities, knowledge of project finance, understanding of alternative models of project governance, leadership and stakeholder management. There was a strong belief that clients need to become more and more integrated in order to move to a position where they are better able to offer a set of logical and consistent voices, for project delivery and management. This means that long-term relationships between clients and integrated supply chains need to evolve to ensure that much greater levels of efficiency in capital delivery can be achieved. However, it is essential to point out that with continuous regulatory, legislative and judicial adjustments, energy organisations operating across borders will be challenged to follow and appreciate ever-changing global developments in the market. A notable feature to this is that strategic adjustments, globalisation, economic realisms and operational change will require energy organisations to follow and identify with strategic internal proposals.

\section{Conclusion and recommendations}

A number of noteworthy issues have been identified that have not been discussed in the energy capital development literature. The issues that have been identified relate to energy capital project delivery and execution strategies. The evidence from this study suggests that delivering major capital energy projects on schedule and to budget will become increasingly challenging for many energy companies. If the challenges are not met, this could impede the sector's ability to manage significant wave of capital investment. What is clear is that unparalleled levels of reserves will be required over the next two decades to meet these challenges. The new strategic priorities (improve efficiency of operation, investment requirements, market resilience) and project delivery processes, if attained, will enable the global energy sector to move forward and deliver growth and build on unique capabilities through carefully targeted investment.

One of the more significant findings to emerge from this study is that although the project management theory and practice have both developed, there are still concerns that: project management theory has been centered around management of projects; and techniques being applied do not explicate the behaviour of complex energy capital projects. In general, therefore, it seems that there is a need to introduce project development and execution theories that reflect the 
complexity of capital projects in the energy sector. The nature of delivering energy projects has changed. Participants indicated that comprehensive innovative project delivery and analytical approaches are required to cope with the increasing scale and complexity of energy capital projects. This accords with an earlier observation made in the literature reviewed, which suggested that science based project techniques such as system thinking, data and analytics will be required to compare estimates on past projects, review variances and analyse causes (Fouche and Rolstadas 2010; Kapasali 2011; Okrie et al. 2012; Yeo 1993).

Project performance and investment will require more than perceptions of risk management, there must be real demonstration and commitment to science based techniques. In addition, the success of front end loading will depend on risk management and development of well integrated technical project teams. The study showed that a capital energy project with a systematically performed front end loading may face unexpected problems during delivery, in spite of the fact that risks have been mapped. This finding is consistent with those of other studies, such as those mentioned in the literature reviewed by Flyberg et al. (2003), Flyberg (2014) and Mckenna et al. (2006), which suggested that organisations should advocate a more explicit acknowledgement of risk in a more accountable approach before the final investment decision is made.

Due to increased project complexity in demanding project environments, capacity decisions, aggressive performance expectations and technological innovations, energy organisations will need to make quantum shifts to deliver quality projects with better performance. Participants indicated that energy organisations cannot afford to miscalculate the complex risks. The literature reviewed reaffirmed that complex commercial arrangements, increased technical, increased technical challenges, evolving local conditions (both economic and regulatory), and a portfolio that is shifting geographically toward frontier regions are all increasing risks and uncertainty in energy capital projects (Graham 1988; Mckenna et al. 2006; Van der Weijde 2008).

Given the complex nature of energy projects, the results showed that robust project management systems need to include the following: project definition, organisational/operating model, adding value, controls and project governance and associated standards (see Figure 1). The findings in this 
study provide a renaissance of capital delivery. It is recommended that further research be undertaken in the following areas: system dynamics, predictive analytics, capital effectiveness, forecasting, estimating, complex risk management and governance. The findings of this study have a number of important implications for future practice. There is, therefore, a definite need for: clients ensure resources are exploited in an efficient way and priorities are taken forward; and clear priorities for science based project delivery processes and knowledge ecosystem needs to be utilised and deployed more rapidly, to help ease delivery and increase recovery levels in the long-term.

\section{References}

Accenture., 2012. Developing strategies for the effective delivery of capital projects: Accenture global survey of the energy industry.

Aleklett, K., Hook, M., Jakobsson, K., Lardelli, M., Snowden, S., Soderbergh, B., 2010. The peak of the oil age-Analysing the world oil production reference scenario in World Energy Outlook 2008, Energy Policy. 38 (3): 1398-1414.

Asche, F., Oglend, A.Osmundsen, P., 2012. Gas versus oil prices the impact of shale gas. Energy Policy, 47: 117-124.

Aubry, M., Sylvain Lenfle, S., 2012. Projectification: Midler's footprint in the project management field. International Journal of Managing Projects in Business, 5 (4), 680-694.

Badiru, A.B. Osisanya, S.O. 2013. Project Management for the Oil and Gas Industry: A World System Approach. CRC Press: Florida.

Berendas, K., 2007. Engineering and construction projects for oil and gas processing facilities: Contracting, uncertainty and the economics of information. Energy Policy, 35 (8): 4260-4270.

Bowler, J.D. Crabtree, E., Keogh, W., 1997. Rhetorics and realities in new product development in the subsea oil industry. International Journal of Project Management, 15 (6): 343-350.

Braun V, Clarke V., 2006. Using thematic analysis in psychology. Qualitative Research Psychology 3(2): 77-101.

British Petroleum (BP). BP Statistical Review of World Energy, British: BP Plc. Available from http://www.bp.com/content/dam/bp/pdf/Energy-economics/statistical-review-2014/BP-statisticalreview-of-world-energy-2014-full-report.pdf [accessed August, 2015].

Bryman, A., 2012. Social Research Methods, $4^{\text {th }}$ ed., Oxford University, Oxford.

Cabrera, D., Colosi, L. , Lobdell, C., 2008. Systems thinking. Evaluation and Programme Planning, 31, 299-310.

Chapman, R.J., 1998. The role of system dynamics in understanding the impact of changes to key personnel on design production within construction projects. International Journal of Project Management, 16 (4), 235-248. 
Cicmil, S., Hodgson, D.E., Lindgren, M. , Packendorff, J. (2009). Project management behind the façade, Ephemera: Theory and Politics in Organisation, 9 (2), 78-92.

DECC., 2013. UK energy projects awarded $€ 75$ million of European funding. Available from: https://www.gov.uk/government/news/uk-energy-projects-awarded-75-million-of-european-funding [Accessed $20^{\text {th }}$ October 2014]

DECC., 2014. Delivering UK energy investment. Available from:

https://www.gov.uk/government/uploads/system/uploads/attachment data/file/331071/DECC Energy Investment Report.pdf [Accessed $20^{\text {th }}$ October 2014].

Deloitte., 2013. The challenge of renaissance: Managing an unprecented wave oil and gas capital projects, cited $\left(17^{\text {th }}\right.$ October 2014), available from: http://www.deloitte.com/assets/DcomUnitedStates/Local\%20Assets/Documents/Energy us er/us er ChallengeOfRenaissance 12202013 .pdf

Denzin, N.K. , Lincoln, Y.S., 1998. Collecting and interpreting qualitative materials, Sage Publications, London.

Dingle, J., 1985. Project feasibility and manageability. International Journal of Project Management, 3 (2): $94-103$.

Eckert, C.M. and Clarkson, P.G., 2010. Design process improvement: A review of current practice. London, UK: Springer-Verlag London Limited.

Erdos, P., 2012. Have oil and gas prices got separated? Energy Policy, 49, 707-718.

Ernst and Young., 2011. Powering the UK: The role of the power and gas sector in the wider economy.

European Union., 2014. European energy infrastructure opportunities: Projects of Common Interest. $2^{\text {nd }}$ Ed, Norton Rose Fulbright. Available from:

http://www.nortonrosefulbright.com/knowledge/publications/120068/european-energy-infrastructureopportunities-projects-of-common-interest [Accessed 16th August 2015].

Eweje, J., Turner, R., Muller, R. (2012). Maximising strategic value from megaprojects: The influence of information-feed-on decision-making by the project manager. International Journal of Project Management, 30 (6): 639-651.

Fallahnejad, M.H., 2013. Delay causes in Iran gas pipeline projects. International Journal Project Management, 31 (1): 136-146.

Feblowitz, J. and Vesset, D., 2013. Recognising the value of untapped data assets: Big data and analytics in oil and gas. IDC Energy Insights.

Flybjerg, B., Bruzelius, N., Rothengatter, W., 2003. Megaprojects and risk-An anatomy of ambition, Cambridge: Cambridge University Press.

Flybjerg, B., 2014. What you should know about megaprojects and why: An overview. Project Management Journal, 45 (2): 6-19. 
Forrester, J.W., 1961. Industrial dynamics, MIT Press, USA.

Fouché, D.P., Rolstadås, A., 2010. The use of performance measurement as a basis for project control of offshore modification oil and gas projects. Production Planning and Control: The Management of Operations, 21(8), 760-773, DOI: 10.1080/09537281003661385.

Frizelle, G.D.M., 1993. Model for maximising the return on capital projects under timing uncertainty. International Journal of Project Management, 11 (1): 39-47.

Fulton, M., Capalino, R., 2014. The trillion-dollar question: Is big oil over-investing in high-cost projects? Available from: http://www.energypost.eu/trillion-dollar-question-big-oil-investing-high-costprojects/ [Accessed $16^{\text {th }}$ August 2015].

Gaisford, R.W., 1986. Project management in the North Sea. International Journal of Project Management, 4 (1): 5-12.

Graham, R., 1988. The future of project management: some North Sea experiences. International Journal of Project Management, 6 (3), 153-163.

Hales, C. and Gooch, S.D., 2004. Managing engineering design. $2^{\text {nd }}$ ed. London: UK, SpringerVerlag London Limited

Harris, J., 2013. Fracking the nation: the dash for gas beneath rural Britain, Guardian Newspaper, Friday $28^{\text {th }}$ June, (cited $17^{\text {th }}$ July 2013), available from:

[http://www.guardian.co.uk/environment/2013/jun/28/fracking-dash-gas-rural-england].

Hodgson, D., 2002. Disciplining the professional: The case of project management. Journal of Management Studies, 39 (6), 803-821.

Horvath, I., 2004. A treatise on order in engineering design research. Research in Engineering Design, 15 (3): 155-181.

Huberman, M. and Miles, B.M., 2002. The qualitative researchers companion, Sage Publications.

Kapsali, M., 2011. Systems thinking in innovation project management: A match that works. International Journal of Project Management, 29, 396-407.

Kjarstad, J., Johnsson, F., 2009. Resources and future supply of oil. Energy Policy, 37 (2), 441-464.

Kloppenborg, T.J. and Opfer, W.A., 2000. Forty years of Project Management research: Trends, interpretations and predictions: In: Project Management Institute Research Conference. Paris PMI PG, pp. 41-59.

Kolltveit, B.J., Karlsen, J.T., Gronhaug, K., 2007. Perspectives on project management. International Journal of Project Management, 25, 3-9.

Koskela, L. and Howell, G., 2002. The underlying theory of project management is obsolete. In Conference proceedings of the PMI Conference. Seattle. Pg. 293-302, (cited $11^{\text {th }}$ August 2013), available from: http://usir.salford.ac.uk/9400/1/2002 The underlying theory of project management is obsolete.pd $f$

KPMG., 2000. The knowledge management research report 2000, (cited $10^{\text {th }}$ September 2013), available from: http://www.providersedge.com/docs/km articles/kpmg km research report 2000.pdf 
Kwak, Y.H., Anbari, F.T., 2008. Analysing project management research: Perspectives from top management journals. International Journal of Project Management, 27, 435-446.

International Energy Agency., 2011. World energy outlook, (cited $16^{\text {th }}$ July 2013), available from: http://www.iea.org/publications/freepublications/publication/WEO2011 WEB.pdf

International Energy Agency., 2014. World energy investment outlook. International Energy Agency. Available from: https://www.iea.org/publications/freepublications/publication/WEIO2014.pdf [Accessed 17th August 2015].

Laidlaw, S., 2011. Securing a bright future: Key speech to the economist UK energy summit $23^{\text {rd }}$ June 2011, (cited $16^{\text {th }}$ July 2013), available from: www.centrica.com.

Lang, M.J., 1990. Project management in the oil industry. International Journal of Project Management, 8 (3), 159-162.

Li, H., Guo, H.L., 2011. Complexities in managing mega construction projects. Editorial for International Journal of Project Management, 29 (7), 795-796.

Lindemann, U., Maik, M and Thomas, B., 2009. Structural complexity management: An approach for the field of product design. Berlin: Germany, Springer -Verlag Berlin Heidelberg.

Lyneis, J.M., Ford, D.N. 2007. System dynamics applied to project management: A survey assessment and directions for future research. Systems dynamic review, 23 (2/3), 157-189.

Manne, A.S., 1967. Investments for capacity expansion: Size, location and timephasing, MIT Press.

Mckenna, G. M., Wilczynski, H., VandeSchee, D. 2006. Capital project execution in the oil and gas industry: Increased challenges, increased opportunities.

McComb , S.A., Kennedy, D.M., Green, S.G., Compton, W.D. 2008. Project team effectiveness: the case for sufficient setup and top management involvement. Production Planning and Control: The Management of Operations, 19 (4), 301-311, DOI: 10.1080/09537280802034059

Meredith, J., 2002. Developing project management theory for managerial applications: The view of a research Journal's editor. In Proceedings of PMI research conference, Seattle, Project Management Institute.

Midler, C., 1995. Projectificaion of the firm: The Renault Case. Scandinavian Management Journal, 11 (4), 363-375.

Mohr, S.H.,Evans, G.M., 2010. Long term prediction of unconventional oil production. Energy Policy, 38 (1): 256-276.

Morris, P.W.G., 1994. The management of Projects. London: Thomas Telford.

Morris, P.W.G., 2010. Research and the future of project management. International Journal of Managing Projects in Business, 3 (1). 139-146.

Morris, P.W.G. 2013. Reconstructing Project Management. London: Wiley-Blackwell.

Myers, M.D., 2008. Research in business and management. London: UK, Sage Publications Limited. 
Nachmias FC, Nachmias D., 1996. Research methods in the social sciences. 5th Ed. UK: Hodder Education.

Nakhle, C., 2007. Do high oil prices justify an increase in taxation in a mature oil province? The case of the UK continental shelf. Energy Policy, 35 (8), 4305-4318.

Ochieng, E.G., Price, A.D.F. 2009. Framework for managing multicultural project teams., Engineering, Construction and Architectural Management, 16 (6), 527-543.

Ochieng E.G., Price, A.D.F., Moore, D., 2013. Management of Global Construction Projects. Hampshire, UK: Palgrave Macmillan's Global Academic, 11-37

Ochieng, E.G. Melaine, Y., Potts, S.J., Zuofa, T., Egbu, C.O., Price, A.D.F. and Ruan, X., 2014. Future of offshore wind energy in the United Kingdom: The way forward. Journal of Renewable and Sustainable Energy Reviews, 39: 655-666.

OGER., 2009. Oil and gas UK the voice of the offshore industry (2011), (cited $6^{\text {th }}$ June 2013), available from: www.oilandgasuk.co.uk.

OGER., 2010. Oil and gas UK the voice of the offshore industry (2010). Oil and gas UK activity survey report, (cited $6^{\text {th }}$ June 2013), available from: www.oilandgasuk.co.uk.

OGER., 2012. Oil and gas UK the voice of the offshore industry (2012). Oil and gas economic report, cited ( $6^{\text {th }}$ June 2013), available from: www.oilandgasuk.co.uk.

OGER., 2013. Oil and gas UK the voice of the offshore industry, (cited $6^{\text {th }}$ June 2013), available from: www.oilandgasuk.co.uk.

Ohara, S., 2009. Framework of contemporary Japanese project management (1): project management paradigm; interpretation, application and evolution to KPM. Japanese project management: KPM-innovation, development and improvement.-Singapore [u.a]: World Scientific, ISBN 978-981-277873. 5-23.

Okrie, T., White, N., Katyal, V., Wallace, S., 2012. Reining in project risk, predictive project analytics: How organisations increase the success rate of complex projects by predicting project performance, (cited $15^{\text {th }}$ June 2013), available from: http://www.deloitte.com/assets/DcomUnitedStates/Local\%20Assets/Documents/AERS/us aers project\%20risk print-

friendly version 081012.pdf

OPSR., 2003. Improving Programme and Project Delivery. UK Civil Service Report-Office of Public Services Reform. Whitehall, London.

Orueta, F.D. and Fainstein, S., 2009. The new mega-projects: Genesis and impacts. International Journal of Urban and Regional Research, 32(4): 759-767.

Pahl-Wostl, C., Craps, M, Dewulf, A., Mostert, E., Tàbara, D. and Taillieu, T., 2007. Social learning and water resources management. Ecology and Society 12(2): $5 . \quad$ [online] URL:http://www.ecologyandsociety.org/vol12/iss2/art5/.

Pinsent Mason., 2011. Infrastructure in the new era: Constructing excellence and Pinsent Masons LLP, Constructing excellence in the built environment. 
Piperca, S., Floricel, S., 2012. A typology of unexpected events in complex projects. International Journal of Managing Projects in Business, 5 (2), 248-265.

PwC., 2008. Building knowledge, capital project procurement-collaboration versus competitive risk pricing?" Engineering and Construction.

PwC Report., 2009. What's wrong with project governance? (cited $18^{\text {th }}$ June 2013), available from: http://www.pwc.co.uk/assets/pdf/capital-project-governance.pdf.

PwC Report., 2010. Engineering growth: Fourth-quarter 2010 global engineering and construction mergers and acquisitions analysis, (cited $18^{\text {th }}$ June 2013), available from: http://www.pwc.com/us/en/industrial-products/publications/engineering-growth.jhtml

PwC Report., 2011. Simplifying your Industrial Business, (cited $18^{\text {th }}$ June 2013), available from: www.pwc.com/uk.

PwC, 2014. Capital project and infrastructure spending: Outlook to 2025. Available from: http://www.pwc.com/gx/en/capital-projects-infrastructure/publications/cpi-outlook/index.jhtml [Accessed 18th August 2015]

Rekveldt, M.B., Jongkind, Y., Mooi, H., Bakker, H., Verbraeck, A., 2011. Grasping project complexity in large engineering projects: The TOE (Technical, Organisational and Environmental) framework. International Journal of Project Management, 29 (6): 728-739.

Richardson, G.P., Vennix, J.A.M., Anderson, D.F., Rohrbaugh, J., Wallace, W.A., 1989. Eliciting group knowledge for model building. In: Milling, P.M. Zahn, E.O. (Eds), Computer-Based Management of Complex Systems, Springer-Verlag, Berlin.

Richards, P., Fell, M. (2013). Shale gas and fracking, Science and Environment Section: House of Commons Library, UK (cited $15^{\text {th }}$ July 2013), available from: http://www.parliament.uk/briefingpapers/SN06073.

Riis, J.O., Pedersen, F.L. 2003. Managing organizational development projects by paradoxes.

Production Planning and Control: The Management of Operations, 14 (4) 349-360.

Rodgrigues, A., Bowers, J., 1996. The role of system dynamics in project management. International Journal of Project Management, 14 (4), 213-220.

Salazar-Aramayo, J.L., Rodrigues-da-Siliveria, R., Rodrigues-de-Almedia, M., De Castros-Dantas, T. N. (2013). A conceptual model for project management of exploration and production in the oil and gas industry: The case of a Brazilian company. International Journal Project Management, 31(4), 589-601.

Scarlat, N., Dallemand, J., Monforti-Ferrario, F. Banja, M and Motola, V. 2015. Renewable energy policy framework and bioenergy contribution in the European Union - An overview from National Renewable Energy Action Plans and Progress Reports. Renewable and Sustainable Energy Reviews, 51(November), pp. 969-985.

Scottish Enterprise Report., 2011. Oil and gas strategy 2012-2020, (cited on $15^{\text {th }}$ July 2013), available from: http://www.scottish-enterprise.com/news/2012/05/new-oil-and-gas-strategy-for-scotland.aspx.

Senge, P., 1990. The fifth discipline: The art and practice of the learning organisation. Doubleday, New York. 
Smith, C., Winter, M., 2010. The craft of project shaping. International Journal of Managing Projects in Business, 3 (1), 46-60.

Soderlund, J., 2003. Building theories of project management: Past research. International Journal of Project Management, 22, 183-191.

Steffen, A., Couchman, J., Gillespie, B., 2008. Avoiding cost blow-outs on minimising capital projects through effective project stage gating, (cited $16^{\text {th }}$ July 2013), available from: http://www.pwc.com.au/industry/energy-utilities-mining/assets/Avoiding-Cost-Blow-Outs-Nov08.pdf.

Suh, N. P., 1990. The principles of design. New York: USA, Oxford University Press.

Suresh, S., Dutto, P., Rogers, S., Kruse, M. 2013. Managing capital projects successfully: An executive concern. Arthur D. Little. Available from:

http://www.adlittle.com/downloads/tx adlreports/Energy-Utilities 2013 ManagingCapitalProjects.pdf [Accessed 17th August 2015]

Ulrich, K. and Eppinger, S., 2003. Product design and development. New York: USA, McGraw-Hill Higher Education

Van der Weijde, G., 2008. Front end loading in the oil and gas industry, Unpublished dissertation, Delft University of Technology.

Vennix, J.A.M., 1996. Group model building: Facilitating team learning using system dynamics. Wiley, New York.

Vennix, J.A.M., 1999. Group model-building: Tackling messy problems, Jay Wright Forrester Prize Lecture System Dynamics Review 15 (4), 379-401.

Wagner, S.M. Kamil J. Mizgier, K.J., Arnez, P. 2014. Disruptions in tightly coupled supply chain networks: the case of the US offshore oil industry, Production Planning \& Control: The Management of Operations, 25(6),494-508.

Weaver, W., 1984. Science and complexity. American Scientist 36, 536 Based upon material presented in Chapter 1' "The scientists speak, "Boni and Gaer Inc, 1947.

Whittington, R., Pettigrew, A., Peck, S., Fenton, E., Conyon, M., 1999. Change and complementarities in the new competitive landscape: An European panel study. 1992-1996, Organisation Science, 1999, $5,583-600$.

Willoughby, K.A., 2005. Process improvement in project expediting: there must be a better way. International Journal of Project Management, 23 (3), 231-236.

Willink, A., 2005. Front-end loading and project delivery, Sinclair Knight Merz Newsletter.

Winter, M., Smith, C., Morris, P., Cicmil, S. (2006). Directions for future research in project management: The main findings of a UK government-funded research network. International Journal of Project Management, 24 (8), 638-649.

Yeo, K.T., 1993. Systems thinking and project management-time to reunite. International Journal of Project Management, 11 (2), 111-117. 
Zhang, H., 2007. A redefinition of the project risk process: Using vulnerability to open up the eventconsequence link. International Journal of Project Management, 25 (7), 694-701.

Appendix 1-Interview questions (Appended interview questions)

\section{Research Aim:}

The overarching aim of this research was to examine project delivery challenges being faced by senior energy practitioners and to determine how they could achieve value and efficiency through better alignment of project delivery processes.

1. Brief background:

- Describe your role and responsibility in the organisation?

- What is meant by energy capital project-please give examples?

2. What are the specific needs of the energy sector and how do these relate to other large capital projects?

3. Do current project management processes act as a focus for strategic long-term thinking?

4. What are the barriers to project management processes being adopted, implemented at strategic, operational and project level?

5. What are the critical project management issues that need addressing on large energy capital projects?

6. Is there a need throughout the energy sector for a fundamental shift in project management?

7. What are the most effective project management tools for delivering energy capital projects?

8. What are greatest needs and/or potential for improving energy project performance and delivery?

9. What are three most important actions to be taken by government, clients, consultants and the supply chain to enable mutual alignment of project management processes?

10. What could be improved to meet future energy needs? 
Dr Edward Ochieng: Senior Lecturer in Project Management at Liverpool John Moores University. Edward has a PhD from Loughborough University. Edward's research is focused on project management. He has extensive experience and knowledge relating to organisational challenges and solution development for managing large capital and heavy engineering projects. Presented at national and international conferences, such as Association of Researchers in Construction Management, Australian Universities Building Educators Association and American Society for Engineering Education where he shared his knowledge on 'project complexity, project performance and team integration'. Edward has published 2 books, 7 book chapters and over $\mathbf{6 0}$ refereed papers.

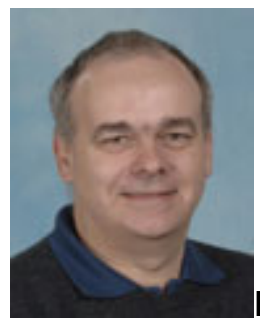

Professor Andrew Price: Professor of Project Management with over 30 years design, construction and industry-focused research experience, with considerable experience of major collaborative funded research projects. Andrew has been the principal or co-author on five books and over $\mathbf{3 0 0}$ refereed journal and conference papers. He has also been the principal or coinvestigator on 24 completed research projects, including: SUMoT Consortia (£1.6M); Loughborough's IMCRC (£26M) over the past 10 years. He is currently Co-Director of the EPSRC funded (£13M over 7 years) Health and Care Infrastructure Research and Innovation Centre (HaCIRIC).

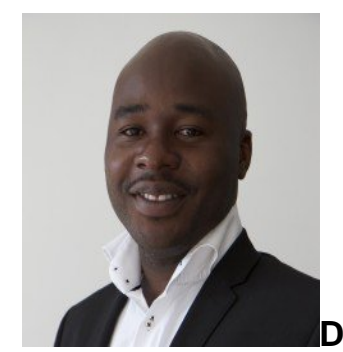

Dr Tarila Zuofa: is a Lecturer in Project Management at the University of Westminster. Tari, has extensively carried out industry and academic oriented research in project management, most of which have focused on key issues such as strategic project management, risk and uncertainty management, knowledge management, multicultural team leadership. His PhD research explored a wide range of issues affecting risk management in the oil and gas industry and project management in general. Part of the novelty of the thesis was highlighted in its uniqueness of providing an excellent opportunity for exploring project management practices in developing and developed countries. 


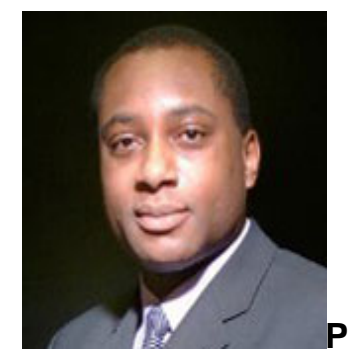

Professor Charles Egbu: is the Dean of School of the Built Environment and Architecture, London South Bank University, London, England, UK. He was formerly at the University of Salford, England, UK, where he was Head of School and Chair in Project Management and Strategic Management in Construction; and Director of the Management in Construction Research Centre. His First Degree was in Quantity Surveying [First Class Honours], Leeds, UK. His Doctorate was obtained from the University of Salford, UK, in the area of Construction Management. Charles has published over $\mathbf{3 0 0}$ papers.

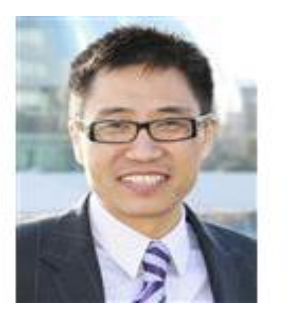

Dr Ximing Ruan: After working in IT and the construction industry for 10 years, I pursued degrees in Northumbria University at Newcastle upon Tyne, including an MBA from the Business School and a PhD in project management from the Built Environment School. I joined the Business Management department at UWE in 2012 after four year's teaching in Aberdeen, Scotland. I am a full member of APM (Association for Project Management) with both APMP and PQ qualifications. 